\title{
ICT Teaching Experience Sharing in Higher Education: an Education Development Approach
}

\author{
Jacky POW \\ Department of Education Studies, Hong Kong Baptist University \\ Kowloon Tong, Hong Kong \\ e-mail: jackypow@hkbu.edu.hk
}

Received: May 2006

\begin{abstract}
With the growing awareness of the scholarship of teaching and the appropriate incorporation of Information and Communications Technologies (ICT) in higher education, there is a need for university lecturers to reflect upon and share their practice in the use of ICT in teaching and learning. This paper aims to study the way lecturers communicate their ICT teaching experience. Specifically, it tries to identify the key elements that are needed to form a model to make sharing of practice more effective. An action research approach was adopted to explore the issue. Nine teacher educators and nine university lecturers participated in different study stages. This paper provides evidence that the use of an issue-based model together with Benzie's (1999) evaluation dimensions, the sharing process and discussions are focused and cover a wide range of aspects in relation to the teaching context, and support a discussion of pedagogy rather than merely technical issues.
\end{abstract}

Key words: teaching experience sharing, use of ICT, education development, evaluation of teaching, higher education.

\section{Introduction}

The primary concern in this study is to develop an understanding of what to share and the process of sharing practice of teaching with ICT among university lecturers. In other words, I want to know more about the way that university lecturers share their practice in using ICT and the important elements that should be included in the sharing process. I am interested in the process of sharing because I want to develop an understanding of the usefulness and effectiveness of a more systematic and structured way of sharing teaching experiences as opposed to the informal ways currently used by university lecturers, i.e., storytelling. My proposition is that a systematic presentation of teaching experience in the form of a model can facilitate the sharing of teaching experience with others by supporting reflection on key elements within their practice.

\section{The Context}

Funding for enhancing learning and teaching with ICT usually gets a high priority in a university budget; it is therefore important that this use of ICT to enhance teaching 
and learning is appropriate (Brennan et al., 1999). Many senior staff, academic staff and experts in higher education believe that ICT has a high potential for improving the way in which students learn (Haywood et al., 2000). However effective incorporation of ICT into teaching is not likely to happen smoothly, as most university lecturers (for example, those in Hong Kong) have not received formal teacher education, and their teaching is to a large extent based on their past learning experience (Bigge and Shermis, 1999). Since ICT teaching is new to most faculty, there is no past experience for them to learn from. This may result in improper uses of ICT and these inappropriate uses may hinder, rather than facilitate, student learning (Richards, 1999). A formal approach to the sharing of ICT teaching experience that facilitates reflection might help improve this situation. Following the work of Boyer (1990) in 'Scholarship Reconsidered', there has been an increasing popularity in the idea of scholarship of teaching as a result of the growing awareness of the need for quality assurance in university teaching (Martin, 1999). In this respect, this study is timely in that it takes a close look at how university lecturers take advantage of ICT to enhance their teaching in a scholarly manner.

In many universities, the role of the lecturer still remains as a knowledge provider. The job is perceived as one of knowledge transmission through lecturing to the students. Since lecturing seems to be a cost effective method of knowledge transfer (Edwards, Smith and Webb, 2001), lecturers do not feel the need to develop new and innovative teaching methods such as the effective use of ICT in teaching. As technology advances, ICT will no longer be seen as something that is optional, but will be viewed as a new teaching pedagogy that will have a major impact on education (Steinkraus, 2001). Most of the changes in the use of ICT in learning and teaching (Langlois, 1998) have inevitably required teachers to acquire a certain level of ICT competency so as to cope with the technological and pedagogical changes. Wiebe and Harriet (1997) point out that ICT competency has become a core requirement of teaching credentials and should form part of the accreditation standards. However, in universities many of these accreditation standards are not directly applicable since the academic staff are trained to be scholars in their field and are recognized primarily for their research skills and output and not for their teaching ability (LaPidus, 1987). Many of them will not have received any kind of didactic or pedagogical training before they became lecturers in universities (Weimer, 1990). The position as stated by Weimer in 1990 has not changed significantly:

A substantial number of Ph.D.'s today start jobs in college and universities never having taught before and never having any formal instruction in how to teach.

(Weimer, 1990, p. 9)

The consequence is that their teaching will tend to only replicate what they have previously encountered in their undergraduate courses (Bigge and Shermis, 1999). For that reason, lectures are mostly used as the major vehicle for teaching, i.e., for delivery of information (Dittmer, 1999; Edwards, Smith and Webb, 2001). Problems arise when ICT is incorporated into teaching because it demands a high level of pedagogical and technological competency from teachers in order to be able to deliver the teaching materials effectively. 
This remains particularly true in the Hong Kong context. This paper argues that there is a need to have formal models to facilitate the sharing of teaching experience as a way of professional development. Models that are capable of capturing the semantic of a teaching experience are meant to be an effective platform for "reflection, inquiry, evaluation, documentation and communication" (Trigwell et al., 2000, p. 156), the major attributes of scholarly teaching (Trigwell et al., 2000). Hence, this paper explores the ways a model writing framework or formal model might support these 'untrained' lecturers to appropriately and effectively adopt ICT in their teaching, i.e., to support pedagogic discourse. The idea is to find a formalised and systematic way to exchange teaching experience that enables academics to acquire the kind of professionalism in their teaching as that which they have acquired in their research.

\section{Teaching Experience Sharing}

Laurillard (2002) reaffirms the importance of learning from teaching experience especially when new technologies or methods are involved. Her work regarding a conversational framework for effective use of learning technologies indicates the importance of teaching experience sharing in professional development. She writes:

A new medium and method rarely works well in its first implementation, but the academic community is failing to learn the lessons of experience. Too few academics build on each other's previous work in the field; journal articles do not critique others' work, they only mention it; research and development projects do not build on what has gone before, so the same conclusions are continually repeated. Innovation in the teaching of a subject does not match the standards of innovative research in the subject itself. We should be building a body of knowledge of how best to use learning media; and creating a teaching profession that knows what it is doing and why.

(Laurillard, 2002, p. 6)

This study probes the following questions. What are the elements that affect the appropriate incorporation of ICT into teaching and learning? How can these elements within a particular context be identified? How can these elements be presented systematically so that teachers can make sense of them and engage in discussion about them? Finally these are developed into the two main research questions of this study:

[1] What models might lecturers use to describe their ICT teaching experience?

[2] What are the important elements within these models?

\section{The Evaluation of Innovative Teaching}

For this study I needed to identify an analytical framework to see whether ICT teaching experience sharing can be useful in improving teaching. This evaluation framework needed to set a boundary for experience sharing and be flexible enough to evaluate innovative teaching in a formative way. 
There are various approaches to teaching evaluation but they do not focus on ICT teaching experience sharing. Take Ehrmann's (1998) Flashlight Project as an example, it has an evaluation toolkit that "can be used to study the kinds of progress that are actually happening in most places" and "can be used to check whether some of our most common fears about technology are coming true" (Ehrmann, 1998, p. 1). This approach is based on two basic premises: [1] technology per se does not determine learning outcomes and [2] it is difficult and sometimes impossible to evaluate local uses of technology by comparing learning outcomes (Ehrmann, 1998, p. 3). Thus, Flashlight focuses on studying the changes in practice. It is more concerned with the relationship between the use of technology and outcomes and is not particularly interested in analyzing the processes involved in the improvement. This differs from the approach to evaluation to be used in this study.

After having analysed a range of evaluation methodologies, Oliver (1997) derived a new framework for evaluating the use of educational technology by drawing together the strengths of illuminative (Draper et al., 1996) and experimental methodologies (Muller, 1985). He argued that this hybrid framework is capable of identifying both contextual and generic benefits of technology use in education across a wide range of educational settings. However, this new framework advocates comparative studies and as a result, does not provide an evaluation framework that meets the need of this study.

Joyes (2000) on the other hand proposes a practical framework for formative evaluation of ICT teaching with the direct involvement of both teachers and students. His study suggests that it is the learning and teaching culture that determines the success of the evaluation in changing practice and that to achieve this, lecturers need to fully participate in the process of developing and contributing to the design of the evaluation. This is especially true when the evaluation is summative in nature and is perceived to be judgmental. This approach offers a framework for support for decision-making at the planning stage, it however does not provide a mechanism for teaching experience sharing for teaching improvement.

All the above approaches (Ehrmann, 1998; Oliver, 1997; and Joyes, 2000) do not provide an analytical framework that is suitable to evaluate the effectiveness of ICT teaching experience sharing in this study because they are not developed based on the fundamental reasons of the failings of many large-scale programmes (Benzie, 1999). Benzie (1999) proposes a formative evaluation framework based on summative evaluation of some large-scale programmes because he claims that the summative evaluation of these programmes can provide key insights into the reasons why they have 'failed'. These insights can then be used as part of an exercise to develop a formative evaluation framework that, in turn, can help to shape effective and worthwhile programmes in their early stage of design and implementation. After having reviewed the insights, Benzie (1999) identifies six dimensions for formative evaluation of programmes that are designed to bring ICT related innovation to teaching and learning. The six dimensions that affect innovative teaching are: Attitude, Culture, Beliefs, Values, Knowledge and Resources. He argues that these dimensions can help evaluate an innovative programme at individual, institutional, as well as education system levels (Benzie, 1999). This evaluative framework at 
individual level is considered suitable in this study because this framework consists of the necessary criteria to evaluate an innovative teaching method (i.e., the use of ICT in teaching) that should be covered in the sharing. Although not intended for use in teaching experience sharing, this framework at individual level provides guidance or a boundary for the sharing, and allows for flexibility. However, in order to suit the need of this study, I adapted Benzie's (1999) six dimensions that affect innovative teaching to the context of higher education. Table 1 summarises the adapted Benzie's (1999) dimensions.

In this study, I have adopted Benzie's (1999) framework as a formative evaluation approach to judge whether formal models can facilitate ICT teaching experience sharing. In order to do this, a definition that sharing is more effective when it covers more dimensions in the process is proposed for this study. This definition is based on our experience

Table 1

Six adapted Benzie's (1999) dimensions that affect innovation

\begin{tabular}{|c|c|}
\hline Dimension & Description \\
\hline Attitude & $\begin{array}{l}\text { Refers to the attitude of an individual lecturer towards the use of ICT in teaching and } \\
\text { learning: the extent and strength of attitudes of an individual lecturer had as a determinant } \\
\text { towards the use of ICT in their teaching and learning. }\end{array}$ \\
\hline Culture & $\begin{array}{l}\text { Refers to the cultural (and structural) responsiveness of an individual lecturer towards } \\
\text { change in general: many individual lecturers tend to minimize their need to change their } \\
\text { day-to-day work. To incorporate ICT into their teaching that moves those lecturers from } \\
\text { their habitual pattern of behavior is a very significant challenge. However, to some lecturers, } \\
\text { innovation and change is the cultural norm and their use of ICT in teaching and learning is } \\
\text { more likely to be successful. }\end{array}$ \\
\hline Beliefs & $\begin{array}{l}\text { Refers to the basic beliefs about the nature of teaching and learning. These basic beliefs } \\
\text { can be consistent with, or in opposition to, those associated with the use of ICT: many } \\
\text { lecturers' day-to-day actions are grounded in basic sets of beliefs about the nature of teaching } \\
\text { and learning. When the use of ICT in teaching and learning is in fundamental conflict with } \\
\text { their beliefs, the chance of success will be drastically reduced. }\end{array}$ \\
\hline Value & $\begin{array}{l}\text { Refers to an individual's value judgment in defining the successfulness of innovation: } \\
\text { Student results and the evaluation of teaching are key measures in determining the value that } \\
\text { is placed on a teacher. When the use of ICT has a negative impact on the perceived value of } \\
\text { a teacher's work, it is very unlikely to succeed. }\end{array}$ \\
\hline Knowledge & $\begin{array}{l}\text { Refers to the sufficiency of knowledge of an individual to appropriately incorporate } \\
\text { ICT in their teaching and learning: Knowledge-in-action is a key determinant to the use or } \\
\text { not use of ICT in teaching and learning. This knowledge-in-action must be made accessible } \\
\text { to lecturers if the use of ICT in teaching and learning were to be promoted. }\end{array}$ \\
\hline Resources & $\begin{array}{l}\text { Refers to the sufficiency of physical resources available to support an individual to over- } \\
\text { come technical problems and pedagogical challenges: Lecturers tend to use resources on } \\
\text { a day-to-day basis only when they are readily available. Without physical resources nothing } \\
\text { will happen. Lecturers also need support in a number of ways. They need technical support } \\
\text { to ensure the smooth use of ICT in the teaching and learning process. They need support as } \\
\text { they develop new knowledge-in-action through practice. They also need time for personal } \\
\text { reflection and professional development. }\end{array}$ \\
\hline
\end{tabular}


that sharing in general tend to focus on a particular aspect (e.g., technical knowledge) while paying less attention to other aspects which are equally important to the success or failure of an ICT teaching method. In the other words, the sharing of one aspect alone or a small number of aspects does not convey the range of factors that contribute to the success or failure of a particular case in the use of ICT in teaching and learning. Thus this study assumes that when sharing covers more aspects (or dimensions in Benzie's (1999) terms), a more complete context is shared and that this is therefore is effective.

\section{The Research Method}

This study adopts an action research model. This research uses a range of data collection methods in the different stages, ranging from interviews, focus groups/brainstorming, observations and workshops. Participants come from two publicly-funded tertiary education institutions in Hong Kong. In order to preserve the anonymity of the participants, fictitious names are used for the two institutions in this study, namely the Hong Kong Teacher Education Institution and the Hong Kong Victoria University. Moreover, real names of the participants are not used.

There were a total of five groups of participants in this study and they were labeled Lecturers A to E. Each group consisted of three participants except Lecturers D, which had six participants. Stage I participants (Lecturers A, B and C) were those that worked within the Teacher Education Institute. It was expected that their repertoire in teaching and learning theories would provide more insights and inputs in identifying the important elements for model development. The selected participants in this development stage had some experience of integrating ICT in their daily teaching. These participants had worked with the researcher in a variety of ways to develop their own multimedia teaching materials and therefore were willing to participate in the study. The Stage II and III participants were lecturers who worked in a university. These groups of participants (Lecturers D and E) developed working relationship with me when I was working in the Hong Kong Victoria University. This created an opportunity for me to work with a new sample of university lecturers who were to be the potential users of the models. This had the advantage of potentially widening the generalisability of the outcomes of the study as the

Table 2

Lecturers D and Lecturers E

\begin{tabular}{ll}
\hline \multicolumn{1}{c}{ Lecturers D } & \multicolumn{1}{c}{ Lecturers E } \\
\hline Jade Poon (Social Sciences) & Daniel Cheung (Science and Engineering) \\
Jessica Mak (Business) & Helen Yu (Business) \\
Amy Yu (Social Sciences) & Nick Kwan (Language) \\
Thomas Wan (Business) & \\
Patrick See (Business) & \\
Berry Lai (Social Sciences) & \\
\hline
\end{tabular}


original sample were lecturers from a teacher education institute whereas the new sample were groups of lectures from a wide range of university disciplines. For ease of analysis, fictitious names were given to Lecturers D and Lecturers E (see Table 2).

This whole study has altogether eight study cycles with one naturally developing out of the other. These sub-stages (study cycles) can best be described as occurring in 3 main stages. The 3 main stages are Stage I: model development, Stage II: model validation, and Stage III: model evaluation. While some of the sub-stages were designed to validate the outcomes of the previous sub-stage so as to make the study develop consistently, the nature of these validating sub-stages is different from the model validation main stage.

Fig. 1 is a diagrammatic overview of the research process. However, this paper will mainly report Stage III, the evaluation of the formal models, as it is the stage that may provide some insights into ways the sharing of ICT teaching experience with a formal model can be achieved.

\section{The Analysis}

\subsection{Stage I}

Stage I of the study involved four sub-stages in order to identify what models the lecturers might use to describe their ICT teaching experience (research question 1) and the important elements within these models (research question 2).

This study stage was piloted with Lecturers A to see what models they might use to share their ICT teaching experience. The 3 initial models developed were later found not to be efficient in facilitating the sharing in a validation workshop with Lecturers B. I then decided to first identify the elements that the participants perceived to be important with another group of participants (Lecturers $\mathrm{C}$ ), and then developed the modeling approaches to presenting these identified elements with Lecturers B again. As a result, three conceptual models were established as the groundwork for the next stage of the study.

\subsection{Stage II}

In the interviews with Lecturers D, I made an effort to validate the key elements identified so far by Lecturers C (the teacher educators). As the Stage I models were formed by the elements identified by the group of teacher educators, the elements might not have met the needs of university lecturers. Hence, I was particularly curious to know the university lecturers' reaction towards the teacher educators' elements because the coverage and nature of the elements would determine what could be shared and as a result would directly affect the usefulness of the models.

Lecturers D commented that the conceptual models developed so far were not very helpful in promoting meaningful sharing. They suggested that a model should be built on an issue related to teaching and learning. Lecturers $\mathrm{D}$ gave the following rationale/reasons for introducing a new Issue-Oriented model:

- An issue can facilitate a discussion because it has a central theme. 


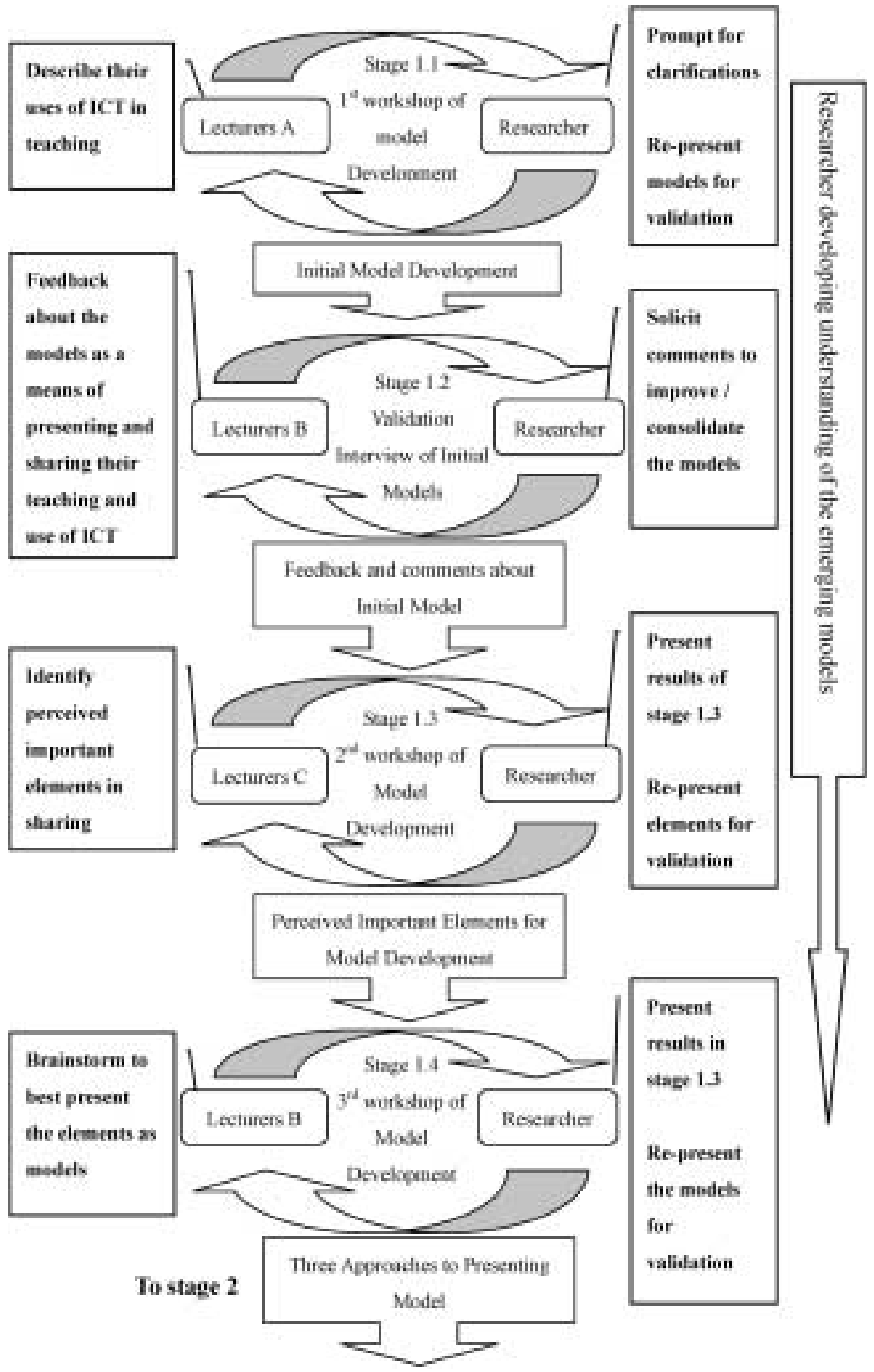

Fig. 1. To be continued 


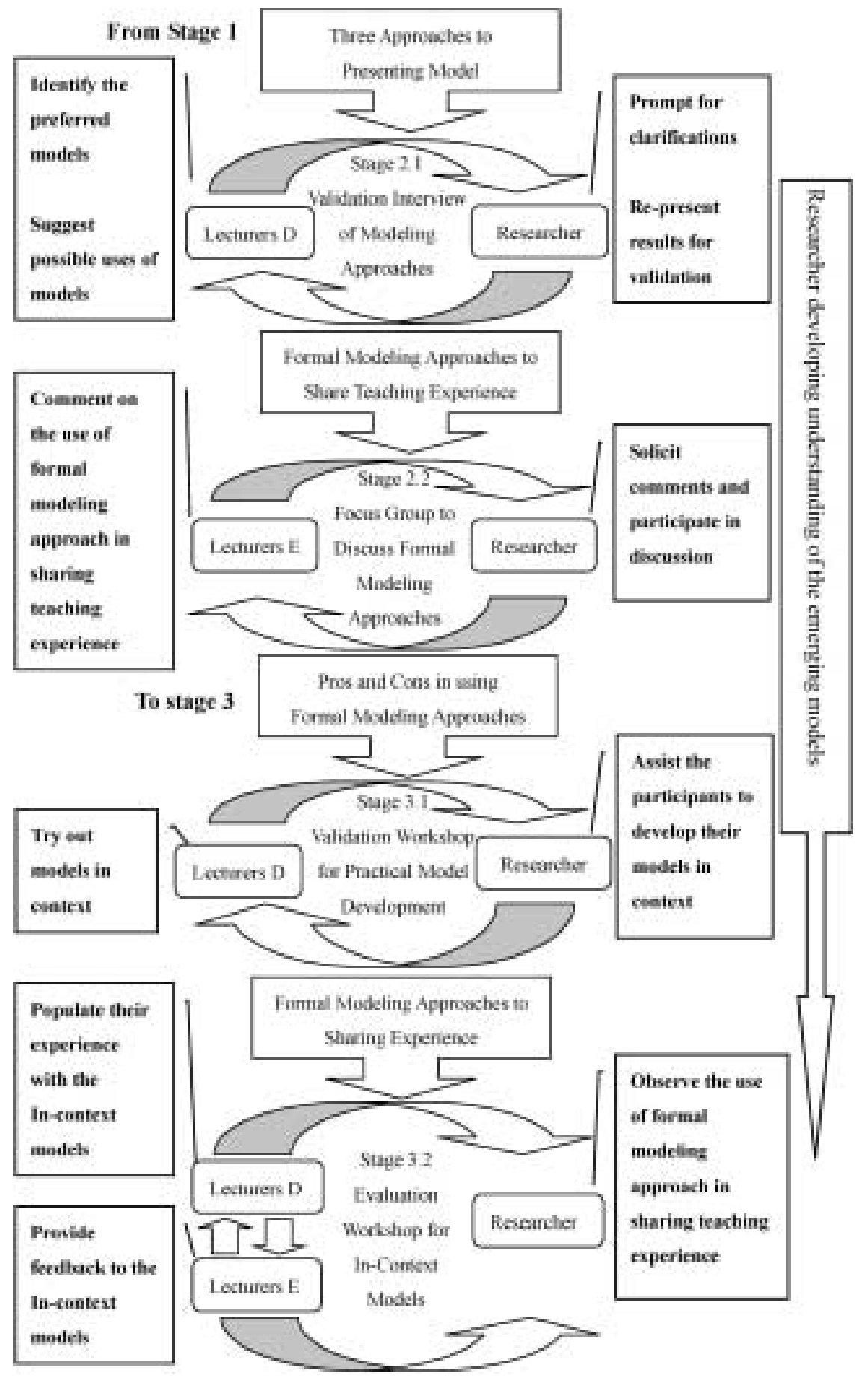

Fig. 1. Summary of the research process. 
- It is the issue that triggers the modeling process and determines the nature of the model.

- The issue can serve as the guiding force to gather relevant information and can make the sharing process more lucid.

- The model is meant to be built to resolve an pedagogical issue.

- It is easier to document a problem.

\section{The Agreed Elements}

In the focus group, Lecturers E eventually arrived at a list of elements that was grouped in 3 dimensions. This forms part of the answer for main research question 2. Table 3 summaries the elements.

\section{The Agreed Model: Issue-Based}

As a result of examining each modeling approach and having tried to fit in the elements in the models, the participants showed a preference for the Issue-based approach to modeling. They felt that the Process-based model was good for plain description but this model would not facilitate effective discussion as well as an Issue-based model. Also, although the Matrix model that combined two procedural models would facilitate comparison, it was felt that it did not provide a clear issue to start off a discussion. The Elements-based model had a highlighting element as the focus of discussion, however it was felt that the purpose of the model was not apparent enough to generate a fruitful discussion. In short, the participants agreed that an Issue-based model would be the most effective and productive approach to facilitating ICT teaching experience sharing of the models identified. This has provided an initial answer to the research question 1.

In this stage I found that participants did not seem to be very interested in sharing teaching experience in general, but were more likely to share their teaching when ICT was involved. Although they were not sure whether formal models could facilitate the teaching experience sharing process, they realised and valued the importance of sharing in teaching improvement. Most importantly, after this stage of the study, there was a

Table 3

Agreed elements to be included in the model.

\begin{tabular}{ll}
\hline \multicolumn{1}{c}{ Dimensions } & \multicolumn{1}{c}{ Lecturers' agreed elements } \\
\hline Pre-teaching & - Teaching aims \\
& - Background of students \\
& - Content and delivery mode \\
\hline Teaching and Learning & - Actual mode of delivery \\
& - Continual adjustment based on students' feedback \\
& - Unexpected issues with possible (or actual) resolutions \\
\hline Post-teaching & - Method of evaluation \\
& - Pros and Cons \\
\hline
\end{tabular}


change in the attitude of the participants towards the use of formal models in the sharing of ICT teaching experience. My experience with both Lecturers D and E was that the participants were skeptical towards the models when they first encountered the notion that the use of a model might facilitate the sharing process. I found that the change in attitude happened after they engaged in the workshop and developed an understanding of the advantages of using a model in documenting and sharing their teaching experience. That implied that a formalized and structured sharing process might have potential in promoting meaningful ICT teaching experience sharing. This change in the participants from an initial skeptical attitude towards the usefulness of the models to a more favourable view towards the models in facilitating the sharing process was an encouragement to me.

\subsection{Stage III}

\section{Development of a Practical Formal Model}

In validating the Issue-based model, I encountered a problem of providing the participants with 'practical' models for sharing because the formal models developed in Stage I and Stage II were described at a conceptual level. I decided to meet with Lecturers D again. I intended to develop some model prototypes with them so that there were usable models for them to try out in context. After some negotiation and discussion, the participants and I decided to build one practical model to try out the practicality of sharing ICT teaching experience rather than developing several of them. As such, a practical model was built with MS Excel, a spreadsheet software package. Fig. 2 shows the model main screen that included an introductory guide setting out the aim of the model and describing how to use it. The elements were arranged in three dimensions with the Main Issue at the top of all the dimensions in this Issue-based model. Each of the elements including the Main Issue was hyperlinked to another screen in which they could provide more detail.

\section{Data Analysis}

The aim of the analysis was to understand the quality of discussions in which the participants engaged so as to evaluate the effectiveness of using a formal model in facilitating the sharing of ICT teaching experience. In the analysis of the sharing sessions, I first used the number of Benzie's (1999) dimensions covered and the overall time spent in the sharing as indicators to determine whether formal models could facilitate the sharing process. For this purpose the original 'knowledge' dimension was split up into two dimensions, knowledge pedagogic issue and knowledge technical issue for this analysis. For this reason this adapted version of Benzie's (1999) dimensions now has 7 rather than 6 dimensions. I coded and grouped the phrases from the discussion with respect to the Dimensions by reading and re-reading the transcripts of the three sharing sessions. I also timed the durations in each dimension by replaying the recorded discussions so as to obtain the patterns of sharing. Finally, I analysed the transcripts to see whether the discussions were focused on the Main Issue and meaningful conclusion could be drawn out from the discussions. 
Model for Teaching Experience Sharing: in Relation to the Use of ICT

Guide for Sharing

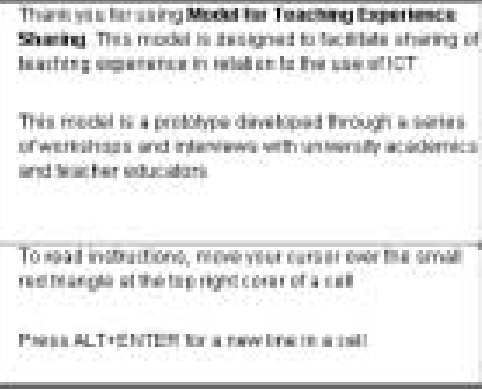

Plosir anes the follewey intoration

Mame: Therran Was

Factily: Eusinwes

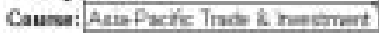

The medel

\begin{tabular}{|c|c|}
\hline & The Man lasiat \\
\hline Pre-teaching & $\begin{array}{l}\text { Texching ame } \\
\text { Bacloround of students } \\
\text { Content and XCT use }\end{array}$ \\
\hline $\begin{array}{c}\text { Tesching and } \\
\text { Leaming }\end{array}$ & 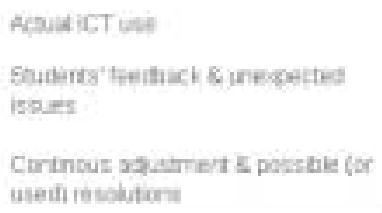 \\
\hline Post'teaching & $\begin{array}{l}\text { Motut of enabian } \\
\text { Fos ind Cirs }\end{array}$ \\
\hline
\end{tabular}

Fig. 2. Main screen of the practical model prototype.

\section{Formal Models Were Effective in Facilitating the Sharing Process}

It was found that all three of the sharing sessions covered more than 4 out of 7 Benzie's (1999) dimensions and that the sharing time in the sharing sessions was rather short. On average, the sharing lasted for 15 to 20 minutes.

\section{Coverage across Benzie's (1999) Dimensions}

In the sharing sessions, I did not find that the participants spent a lot of time clarifying the basic information. Instead, more time was spent in sharing teaching method issues, students' responses, ways of improving teaching methods, and the time needed to adapt to these new teaching methods. Discussions were no longer limited to 'how to apply' ICT. This might have been because the model was serving as a sharing framework that provided the participants with a wider perspective for discussion.

To give a brief idea of the proportion of time spent on issues other than technical ones, I analysed the transcripts of the sharing sessions. I classified and timed the phrases in the transcripts by Benzie's (1999) dimensions. Table 4 shows the approximate percentage of discussion time spent on each dimension. In the figure, an example of the discussion topic is included to illustrate how I matched the areas of discussion to Benzie's (1999) dimensions.

Since the model sharers had time to reflect upon their practice before developing the models and the model receivers also had time to study the model before discussion, it opened up wide areas for discussion. It was to be expected that there would be some 
Table 4

Discussion time spent by Benzie's (1999) dimensions

\begin{tabular}{|c|c|c|c|}
\hline \multirow{2}{*}{ Dimensions } & \multicolumn{3}{|c|}{ Groups } \\
\hline & Jessica and Daniel & Patrick and Helen & Thomas and Nick \\
\hline $\begin{array}{l}\text { Attitude } \\
\text { (How do you feel about using ICT } \\
\text { in teaching?) }\end{array}$ & 1 minute $(5 \%)$ & Nil & 2 minutes $(13 \%)$ \\
\hline $\begin{array}{l}\text { Culture } \\
\text { (Do your colleagues think the same?) }\end{array}$ & 1 minute $(5 \%)$ & Nil & 1 minute $(6 \%)$ \\
\hline $\begin{array}{l}\text { Beliefs } \\
\text { (Do you think this useful?) }\end{array}$ & 3 minutes $(20 \%)$ & 5 minutes $(30 \%)$ & 4 minutes $(25 \%)$ \\
\hline $\begin{array}{l}\text { Values } \\
\text { (Do you enjoy and find it useful to teach with } \\
\text { ICT?) }\end{array}$ & Nil & 1 minute $(6 \%)$ & 2 minutes $(13 \%)$ \\
\hline $\begin{array}{l}\text { Knowledge [Pedagogic issue] } \\
\text { (Your students do not like using the bulletin } \\
\text { board. How do you motivate them?) }\end{array}$ & 12 minutes $(60 \%)$ & 9 minutes $(53 \%)$ & 4 minutes $(25 \%)$ \\
\hline $\begin{array}{l}\text { Knowledge [Technical issue] } \\
\text { (How do you create the virtual case?) }\end{array}$ & 2 minutes $(10 \%)$ & 2 minutes $(11 \%)$ & 3 minutes $(18 \%)$ \\
\hline $\begin{array}{l}\text { Resources } \\
\text { (How much time do you need to build the } \\
\text { case study?) }\end{array}$ & 2 minutes $(10 \%)$ & Nil & Nil \\
\hline
\end{tabular}

discussion about technical issues; but my previous experience was that these would tend to dominate discussions with lecturers at the expense of pedagogic and other issues.

Short sharing time as a result of highly focused sharing

From our observation, there was evidence to suggest that the short sharing time was a result of discussion between the participants being highly focused. First, the model receivers did have relevant questions to ask the model sharers. For example, Nick showed great interest in the consequence of this teaching method and as a start he asked Thomas questions about the students' responses towards the marks:

How did your students feel when they got the examination results from you? Did they come over to you and discuss this with you?

(Nick, Lecturers E)

He then followed with this:

Are you going to change the assessment proportion? Say 30 (per cent) for the examination and 70 (per cent) for the project. I think you haven't mentioned it in your model.

(Nick, Lecturers E) 
This showed that Nick not only had planned questions to ask Thomas but also had advice for Thomas as well. Similar interactions were found in other sharing sessions. This kind of sharing and discussion was considered to be focused as they were highly related to the Main Issue of the model.

Second, the sharing progressed smoothly in the sharing sessions, with very few breaks in the conversations. The participants appeared to know how to locate the necessary information in the model to stimulate dialogue. They could navigate the model easily when they needed information about the issues they were discussing. With the models, model sharers could make reference to the information in the elements to stimulate discussions and the model receivers could address questions around a particular element without any difficulty. In their discussions, I noticed that they cross-referenced their points quite frequently by navigating between elements; this was facilitated by the fact that the model was computer based. For instance, they could check the Actual ICT uses with the Teaching aims with a simple mouse click. Discussion was facilitated through this interaction with the models and as such demonstrated that their discussions were focused and effective. I crosschecked this in the short interviews with them and they regarded the model as a good guide for discussion. They indicated that the model was structured and easy-to-use model and hence facilitated the sharing process. For example, Daniel commented:

The model is concise and user-friendly. It took me less than ten minutes to go through the whole model and I got to know what Jessica was doing with her class ... I found the sharing useful and rewarding.

(Daniel, Lecturers E)

Formal models did not limit the pattern of sharing

In the analysis of Sub-Stage 3.2, I attempted to compare the sharing patterns I observed in the sharing sessions since I wanted to know whether the formal models would limit the pattern of the sharing. The results of this analysis (Table 5) shows, for instance, Thomas and Nick were engaged in a discussion covering all dimensions except resources while Patrick and Helen focused on Beliefs, values, knowledge [both pedagogic and technical]. As such, I realised there was no common sharing pattern and that meant the formal models did not limit the sharing patterns.

Table 5

Sharing patterns by Benzie's (1999) dimensions

\begin{tabular}{lccc}
\hline \multicolumn{1}{c}{ Dimensions } & \multicolumn{3}{c}{ Groups } \\
\cline { 2 - 4 } & Jessica and Daniel & Patrick and Helen & Thomas and Nick \\
\hline Attitude & $\checkmark$ & $\times$ & $\checkmark$ \\
Culture & $\checkmark$ & $\times$ & $\checkmark$ \\
Beliefs & $\checkmark$ & $\checkmark$ & $\checkmark$ \\
Values & $\times$ & $\checkmark$ & $\checkmark$ \\
Knowledge [Pedagogic issue] & $\checkmark$ & $\checkmark$ & $\checkmark$ \\
Knowledge [Technical issue] & $\checkmark$ & $\checkmark$ & $\checkmark$ \\
Resources & $\checkmark$ & $\times$ & $\times$ \\
\hline
\end{tabular}


Discussions Were Focused on the Main Issue and Sub-issues

A detailed analysis of the transcripts revealed that the discussions between the model sharers and the model receiver did focus on the Main Issue and the sub-issues in the other elements of the model. This showed that the issues in formal models did provide guidance or a boundary for the sharing and facilitate the sharing process. The participants tended to start with the Main Issue first and then the other sub-issues in the elements. The following segments of the sharing sessions of Jessica-Daniel and Patrick-Helen illustrate this point and the short interviews after the sharing sessions confirmed it.

\section{Jessica-Daniel's sharing:}

\begin{tabular}{|c|c|}
\hline $\begin{array}{l}\text { Daniel: You mentioned in your model that you created a virtual } \\
\text { business case based on real world data, and you wanted to use } \\
\text { this virtual case to motivate your students. }\end{array}$ & $\begin{array}{l}\text { Daniel started off the discussion with } \\
\text { reference to the Main Issue of the } \\
\text { model. }\end{array}$ \\
\hline $\begin{array}{l}\text { Jessica: Yeah, I think students can learn more in a project based } \\
\text { learning approach in an ICT enriched environment. }\end{array}$ & \multirow{4}{*}{$\begin{array}{l}\text { This generated discussion in Ben- } \\
\text { zie's (1999) Beliefs Dimension. Jes- } \\
\text { sica shared her belief to Daniel. }\end{array}$} \\
\hline Daniel: Why do you think so? & \\
\hline $\begin{array}{l}\text { Jessica: Oh, actually the virtual case is a listed company in Hong } \\
\text { Kong. I changed its name and some of its background. I used the } \\
\text { data in the financial statements of its annual report. Then I put } \\
\text { it up on WebCT so that I can update the case easily. Through } \\
\text { this approach, the students can learn how to conduct a real piece } \\
\text { of business research and to write a report by interpreting real } \\
\text { statistical data for business decision. }\end{array}$ & \\
\hline Daniel: Do you think this approach useful? & \\
\hline $\begin{array}{l}\text { Jessica: To a certain degree, yes. The students knew that the case } \\
\text { was an authentic case and they were using real statistical data in } \\
\text { their project. My ability to update the case online made the case } \\
\text { even more challenging. }\end{array}$ & Daniel seemed to agree by nodding. \\
\hline $\begin{array}{l}\text { Daniel: Well, when I read your model, it seemed to me that your } \\
\text { students do not like using the technology to communicate. How } \\
\text { do you motivate them? }\end{array}$ & $\begin{array}{l}\text { Daniel referred to the model again to } \\
\text { start another discussion based on the } \\
\text { sub-issue in the Pros and Cons ele- } \\
\text { ment. }\end{array}$ \\
\hline $\begin{array}{l}\text { Jessica: I don't know. I set up a bulletin board to let students } \\
\text { discuss some current economic issues, but it is not very popular. } \\
\text { Any suggestion? }\end{array}$ & $\begin{array}{l}\text { This generated discussion in Benzie's } \\
\text { (1999) Knowledge [pedagogic issue] } \\
\text { Dimension. }\end{array}$ \\
\hline $\begin{array}{l}\text { Daniel: My students are getting along with a bulletin board quite } \\
\text { well. They will share their algorithms of their exercise there. Not } \\
\text { the whole algorithm, just part of it. Maybe you may encourage } \\
\text { your students to interpret their data with the current economic } \\
\text { issues and to include the results in the final report. Do you think } \\
\text { it will work in your case? }\end{array}$ & $\begin{array}{l}\text { Daniel tried to provide some construc- } \\
\text { tive ideas to improve Jessica's ap- } \\
\text { proach. }\end{array}$ \\
\hline
\end{tabular}


Patrick-Helen's sharing:

\begin{abstract}
Helen: Hi Patrick. From the Main Issue of your model, I learned that you prepared a web-based course, but your students did not like that. Hence, you turned some of your tutorials into lectures. So you use e-mail as a communication means to compensate the loss of tutorial time. Was it the first time you had run a webbased course? What actually was it that you wanted to share in your model?

Patrick: This was not my first time to run a web-based course. I have used WebCT for some of my courses. This time I tried to reduce the number of lecture and to have small group tutorials instead. I did not expect that the students would like to have more lectures instead of self-learning on the Web with tutorials. I think this is a good approach ...
\end{abstract}

Helen: What would you do if you were to run this course again? Will you try your original approach again or will you adjust your approach?

Patrick: I belief that my approach will work well. I have put up a lot of materials on WebCT. If the students can study the facts and concepts on the Web first and then bring up what they did not understand in the tutorials, they will learn more than in a lecture.

Helen: You say here (referring to the Continual Adjustment and Possible resolutions element), you sent e-mail to the students each week and they had to send you back the answers in e-mails within the week. There would be a lot of e-mails. How could you manage that?

Patrick: Oh, I should have included this part in my model. OK. I asked the students to rank their own understanding about the topics that I'm going to teach in the next lecture. Everyone of them needed to send me e-mails and provided their own rankings in the e-mail 'subject' so that I can auto-sort them with my email software. It could provide me with some general ideas about their level of understanding of the topics. I could then adjust my materials in the coming lecture accordingly. I learned this from a professional development workshop. This is called 'just-in-time teaching,

Helen: That's interesting. This is the first time I heard of this teaching method. How do you 'filter' the e-mails? Tell me more about it?
Helen instigated the discussion based on the Main Issue.

This generated discussion in the Benzie's (1999) Beliefs Dimension.
Helen turned to the model and started another discussion topic based on a sub-issue in the Continual Adjustment and Possible resolutions element.

This generated sharing in Benzie's (1999) Knowledge [pedagogic issue] Dimension.

\section{Meaningful Discussions were Emerged}

Although the time need for the sharing was rather short, it was found that the sharing could help to draw meaningful conclusions or solutions for the issue. Through this kind of interactive sharing with the help of the models, the participants appeared to have a common objective in the sharing - either to develop more understanding about the problem that associated with the Main Issue or looking for a solution to the Main Issue. 
Helen, the model receiver, learned the use of 'just-in-time' teaching method and Patrick promised her to tell her more about it some other time. Patrick on the other hand realised that he should have included the use of 'just-in-time' teaching in his model if he were to share his model with others again.

Regarding Jessica, she would consider Daniel's suggestion to add the discussion of the current economic issues in the bulletin board as a requirement of the student projects. As for Daniel, he would try to use project-based learning approach in one of his courses to test out the effectiveness of the approach.

\section{Reflection}

In the analysis of the sharing sessions, I used time and the coverage of Benzie's (1999) Dimensions as indirect indicators to assess the usefulness of the models in facilitating the discussion. However, the reduction in the amount of time spent and the increase in number of Dimensions covered might not fully reflect the effectiveness and usefulness of a model in facilitating meaningful sharing. I therefore interpreted the sharing sessions transcripts to see whether the sharing was related to the Main Issue which I used as an indicator to determine how focused the discussion was. It is however difficult to predict the usefulness of the formal models in real contexts as the sharing sessions in this study were deliberately set up and did not happen spontaneously.

In this sub-stage, I noticed that the participants did exchange their teaching experience with each other in a rigorous and academic manner. The findings from the short interviews with the participants indicated that the formal model was a useful tool for facilitating sharing and promoting dialogue about teaching and learning amongst lecturers. This provided evidence that the formalized sharing of ICT teaching experience was useful in promoting a meaningful dialogue amongst lecturers because of its systematic approach.

\section{Implications}

As a result of this action research process, the following benefits of the use of formal models were identified:

(1) This asynchronous formalised approach to sharing provides relevant information to the model receivers and allows more time for them to prepare before the actual sharing. In this way, model users (the sharers and the receivers) can discuss and share experience directly reducing the need to clarify basic information;

(2) With the Main Issue to form the heart of the models, model receivers can have a more focused discussion, and at the same time it provides guidance to support a meaningful sharing process;

(3) As the elements in the formal models provide a wide range of information, model receivers can generate more discussion and sharing based on the information in the elements. In other words, not just the technical issues, but other aspects in relation to teaching and learning can also be included in the sharing; 
(4) A formal issue-based model provides a means for the model receiver to engage in a critique of practice.

This formalised and systematic approach to sharing ICT teaching experience enables both the model sharers and the model receivers to engage in a genuine dialogue that is no longer a telling of a story of a teaching incident but a meaningful discussion about pedagogy. This was made possible because the model receivers focus on the Main Issue as the theme for discussion: to ask questions, to reflect and to offer advice or solutions.

However, findings of this study also revealed that the sharing of ICT teaching experience whilst being made possible by the models, it was the culture that determined the effectiveness of the sharing. When such a sharing culture existed, it was felt that these models would be of great value in facilitating sharing.

\section{Conclusion}

The concept of formal modeling to facilitate communication is not new (e.g., Loucopoulos and Zicari, 1992). However, applying a formal model to teaching experience sharing and to develop this model in a participative way is innovative. This exploratory action research revealed that the lecturers involved regarded the formal and systematic sharing of ICT teaching experience they were engaged in to be useful in promoting an efficient and meaningful dialogue. Although the lecturers were initially skeptical towards the use of the formal models for sharing, as they gained experience of their use, they considered them to be a good tool in documenting and sharing their teaching experience and for supporting dialogue and reflection. Moreover, they found that the sharing process tended to focus on pedagogical issues rather than technical issues however no particular sharing pattern was identified.

Our understanding of the role of a formal model in experience sharing informs us that its use to promote the sharing process is not just a change of our own practice, but is a work of a blend of relationships, of understandings, of practices and of academic pursuits that has helped us to better prepare for our work in professional development. To us, as educators, teaching should be treated as stringently as research if teaching is to regain its recognition as scholarly work (Boyer, 1990). Teaching should hold an esteemed place in universities, and not be viewed as something 'inferior' to the scholarship of discovery, application and integration (Boyer, 1990; Hutchings and Shulman, 1999). This study provides evidence to support the notion that reflecting upon and sharing of ICT teaching experience can be effective if it is a formalized activity. It is my belief that it is through this formalized approach to reflecting and sharing that teaching can become a scholarly activity and this research provides some insights into ways this can be achieved.

\section{References}

Bigge, M.L., and S.S. Shermis (1999). Learning Theories for Teachers, 6th ed. Longman, New York. 
Benzie, D. (1999). Formative Evaluation: can models help us to shape innovative programmes? Education and Information Technologies, 3(4), 251-262.

Boyer, E.L. (1990). Scholarship Reconsidered: new priorities of the professoriate. Carnegie Foundation for the Advancement of Teaching, Princeton, N.J.

Brennan, J., D. Dill, T. Shah, A. Verkleij and D. Westerheijden (1999). A Campaign for Quality: Hong Kong Teaching and Learning Quality Process Review. University Grants Committee.

http: //www.ugc.edu.hk/english/documents/tlqpr/tlq-fr-r.html.

Dittmer, A. (1999). The daunting task of faculty development. In V.M. Rentel and A. Dittmer (Eds.), Themes and Issues in Faculty Development. University Press of America, Maryland.

Draper, S.W., M.I. Brown, F.P. Henderson and R. McAteer (1996). Integrative Evaluation: an emerging role for classroom studies of CAL. Computers and Education, 26(1-3), 17-32.

Edwards, H., B. Smith and G. Webb (2001). Lecturing: Case Studies, Experience and Practice. Kogan Page, London.

Ehrmann, S. (1998) The Flashlight Project: tools for monitoring the progress of our hopes and fears about technology in education. The Technology Source, July.

http://ts.mivu.org/default.asp? show=article\&id=83.

Haywood, J., C. Anderson, H. Coyle, K. Day, D. Haywood and H. Macleod (2000). Learning Technology in Scottish Higher Education - a survey of the views of senior managers, academic staff and 'experts'. Association for Learning Technology Journal, 8(2), 5-17.

Hutchings, P., and L. Shulman (1999). Scholarship of teaching: new elaborations, new developments. Change, 31(5), 10-15.

Joyes, G. (2000). An evaluation model for supporting higher education lecturers in the integration of new learning technologies. Educational Technology \& Society, 3(4), 56-65.

Langlois, C. (1998). Universities and new information and communication technologies: issues and strategies. European Journal of Engineering Education, 23(3), 285-295.

LaPidus, J.B. (1987). Preparing Faculty: graduate education's role. AAHE Bulletin, May-June, 3-6.

Laurillard, D. (2002). Rethinking University Teaching: a Conversational Framework for the Effective Use of Learning Technologies, 2nd ed. Routledge-Falmer, London.

Loucopoulos, P., and R. Zicari (Eds.) (1992). Conceptual Modeling, Database and CASE: an Integrated View of Information Systems Development. Wiley, New York.

Martin, E. (1999). Changing Academic Work: Developing the Learning University. Society for Research into Higher Education and Open University Press, Buckingham.

Muller, E. (1985). Application of experimental and quasi-experimental research designs to educational software evaluation. Educational Technology, 25(October), 27-31.

Oliver, M. (1997). A Framework for Evaluating the Use of Educational Technology. BP ELT Report No. 1, University of North London.

Richards, R.T. (1999). Lessons learned from teaching with technology: a critical perspective. TechTrends, 43(4), 31-33.

Steinkraus, E. (2001). New paradigms for education. Journal of Instructional Delivery Systems, 15(2), 31-32.

Trigwell, K., E. Martin, J. Benjamin and M. Prosser (2000). Scholarship of teaching: a model. Higher Education Research and Development, 19(2), 155-168.

Weimer, M. (1990). Improving College Teaching: Strategies for Developing Instructional Effectiveness. JosseyBass, San Francisco, Calif.

Wiebe, J.H., and G. T. Harriet (1997). What should teachers know about technology? A revised look at the ISTE foundations. Journal of Computing in Teacher Education, 13(4), 5-9. 
J. Pow received his $\mathrm{PhD}$ (education) from the University of Nottingham, UK in 2003. He also holds an MSc in information management from the University of Sheffield, U.K., an MPhil in information systems from the City University of Hong Kong, and a postgraduate diploma in education from the University of Hong Kong. He is currently a professional member of the British Computer Society and was the membership secretary and an active Executive Committee member of Higher Education Research and Development Society of Australasia, Hong Kong Chapter (HERDSA HK). He has a research and professional interest in the enhancement of learning and teaching with technologies, formal modeling for ICT teaching experience sharing, professional development framework in ICT in education, and educational multimedia development.

\section{IKT mokymo patirtis auštajame moksle: švietimo plètros metodas}

\section{Jacky POW}

Augant bendram mokymo supratimui ir atitinkamam informaciniu ir komunikaciniu technologijų (IKT) inkorporavimui ị aukštaji mokslą, universitetų dẻstytojams kyla poreikis nuodugniau apmąstyti IKT vietą mokyme ir mokymesi bei dalintis savo patirtimi. Straipsnyje nagrinejjami būdai, kuriais dèstytojai bendradarbiauja dalindamiesi IKT dèstymo patirtimi. Ypatingas dèmesys koncentruojamas i pagrindinius elementus, reikalingus tam, kad būtu sukurtas modelis, leisiantis dalinimąsi patirtimi padaryti veiksmingesnị. Nagrinejjant rūpimus klausimus pasitektas veiksmu tyrimo metodas. Skirtingose tyrimo pakopose dalyvavo devyni mokytojai ir devyni universitetu déstytojai. Straipsnyje pateikiami argumentai, jog dalykinis modelis (anglu k. issue-based model) kartu su Benzie pateiktomis vertinimo dimensijomis bei dalijimosi patirtimi procesas ir diskusijos koncentruojasi ir apima platu aspektu, susijusių su mokymo kontekstu, spektrą ir yra veikiau pedagoginių diskusijų objektas nei vien tik techninių klausimų dalis. 